\title{
KOMPETENSI SUPERVISI, KEPRIBADIAN, DAN SOSIAL KEPALA MADRASAH DI PROVINSI PAPUA BARAT
}

\section{Competence of Supervision, Personality, and Social of Head Madrasah at West Papua Province}

\author{
Oleh: Abdul Rahman Arsyad* \\ * Peneliti pada Balai Penelitian dan Pengembangan Agama Makassar \\ Kantor Jl. A. P. Petta Rani No. 72 Makassar \\ E-mail: rahmanarsvad70(S>,yahoo.com
}

\begin{abstract}
Abstrak
Penelitian ini bertujuan untuk mengungkap kompetensi kepala madrasah di Provinsi Papua Barat, dengan melihat aspek supervisi, kepribadian, dan sosial pada Madrasah Ibtidaiyah, Tsanawiyah, dan Aliyah baik negeri maupun swasta di Kota/Kabupaten Sorong. Penelitian ini menggunakan metode kuantitatif dalam analisis data selain angket/quesioner dengan pendekatan survei, berupaya untuk mengetahui kompetensi kepala madrasah terhadap kepemimpinannya.

Penelitian ini menggunakan metode kuantitatif dalam analisis data selain angket/quesioner akan dianalisis secara deskriptif kualitatifuntuk mengetahui kecendrungan guru terhadap kompetensi kepala madrasah terpilih. Hasil analisis disajikan lewat data, tabel dan grafik. Hasil penelitian ini menunjukkan bahwa tingkat kompetensi kepala madrasah MI, MPs, MA negeri/swasta. Secara keseluruhan kompetensi kepala madrasah terkategori Sedang dengan nilai rerata 62,33. Menurut penilaian guru terhadap kompetensi kepala madrasah MI, MPs, MA negeri/swasta. Hal ini menunjukkan bahwa kepemimpinan kepala madrasah terkategori Tinggi dengan skor rerata 3, L
\end{abstract}

Kata Kunci: Kompetensi Kepala Madrasah.

\section{Abstract}

This Study aims to uncover the head competence Madrasah in west Papua Province, by looking at aspect of supervision, personality, and social at the madrasah Ibtidaiyah, Tsanawiyah and both public and private Aliyah in the city/conty Sorong. This study uses quantitative methods, in addition to questionnaire data analisys/questioner with the survey approach, sleeks to know the competence of the head of madrasah against his leadership.

This study uses quantitative metods in data analisys in addition to the quesitionnere/questioner will be analysis descriptively to determine the qualitative tendence of teachers to the competence of chief elected madrasah. The data obtaired through interviews, study documentation. The data, table and graphs. The results of this study indicate that the level of competence of the head of madrasah MI, MTs, MA public/ private. Overall competence categorized madrasah moderate head with a mean value of62,33. According to the assessment of competence of the head teacher of the madrasah MI, MTs, MA public/private. Shows that the leadership of the high madrasah categorized by the everage Score of 3,1.

Keywords: Head of Competence Madrasah.

\section{PENDAHULUAN}

$\mathrm{K}$ epala madrasah sebagai pemimpin lembaga pendidikan harus mampu melakukan Kesuksesan kepemimpinan kepala madrasah dalam aktivitasnya dipengaruhi oleh faktor-faktor yang dapat menunjang keberhasilan suatu kepemimpinan. Oleh sebab itu, suatu tujuan akan tercapai apabila terjadinya keharmonisan dalam hubungan atau interaksi yang baik antara atasan dengan bawahan, di samping dipengaruhi oleh latar belakang yang dimiliki pemimpin, seperti motivasi diri untuk berprestasi, kedewasaan dan keleluasaan dalam hubungan sosial dengan sikap-sikap hubungan manusiawi.

Senada dengan arah kebijakan dan strategi Kementerian Agama Tahun 2010-2014, antara lain peningkatan kualitas lembaga pendidikan agama seperti raudhatul athfal, madrasah, perguruan tinggi agama, pendidikan agama, dan pendidikan keagamaan, dengan sasaran terwujudnya pelayanan pendidikan yang merata, bermutu dan berdaya saing, serta mampu memperkuat jati diri bangsa, yang ditandai dengan 
diantaranya meningkatnya mutu pendidikan agama di sekolah, meningkatnya profesionalitas dan kesejahteraan pendidik dan tenaga pendidik, dan meningkatnya mutu pengelolaan pendidikan agama dan pendidikan keagamaan.

Dalam dunia pendidikan kepala madrasah merupakan seorang pendidik (guru) yang diberi tugas tambahan. Oleh sebab itu, kepala madrasah di samping sebagai pendidik juga sebagai kepala yang bertanggung jawab terhadap administrasi pendidikan.

Penelitian tentang Kompetensi Kepala Sekolah telah dilakukan oleh Direktorat Tenaga kependidikan Ditjen Peningkatan Mutu Pendidik dan Tenaga Kependidikan (Depdiknas 2007). Dilakukan di 30 provinsi dengan 494 Kepala sekolah dan calon kepala sekolah sebagai sampel penelitian. Hasil uji kompetensi kepala sekolah tersebut terdapat kecenderungan berada pada kategori sedang dengan skor rerata 41,72 . $^{2}$

Terkait kompetensi kepala madrasah aliyah penelitian yang telah dilakukan oleh Achmaduddin, dkk pada tahun 2006. ${ }^{3}$ Penelitian ini dilakukan di 7 kota besar, yakni Bandung, Yogyakarta, Surabaya, Banjarmasin, Palembang, Padang dan Medan, sampel penelitian adalah kepala madrasah di masing-masing wilayah yang terdiri atas kepala Madrasah Aliyah Negeri dan S wasta. Hasil penelitian menunjukkan bahwa pada kompetensi kepala MA bidang pengetahuan pada aspek kepemimpinan, administrasi, dan supervisi ternyata kurang, namun pada aspek manajerial dan pendidikan ternyata baik. kompetensi bidang kinerja pada aspek kepemimpinan, administrasi dan supervisi ternyata cukup, sedangkan pada aspek manajerial dan pendidikan ternyata baik. Dan terdapat perbedaan signifikan antara kinerja kepala MAN dan MAS, terdapat korelasi yang signifikan antara pengetahuan kepemimpinan dengan kinerja kepala MA dan antara tingkat pendidikan dengan kinerja kepala MA.

Berdasarkan latar belakang di atas, maka permasalahan yang diangkat adalah: Bagaimana kompetensi kepala madrasah pada aspek supervisi, kepribadian, dan sosial di Kota/Kabupaten Sorong?

\section{Tinjauan Pustaka}

\section{Kompetensi}

Supandi dalam Wahyudi, bahwa kompetensi adalah seperangkat kemampuan untuk melakukan suatu jabatan, dan bukan semata-mata pengetahuan saja. ${ }^{4}$ Kompetensi menuntut kemampuan kognitif, afektif, nilai-nilai, dan keterampilan tertentu yang khas dan spesifik berkaitan dengan karakteristik jabatan atau tugas yang dilaksanakan. Spesifikasi kemampuan tersebut dimasudkan agar kepala madrasah dapat melaksanakan tugas secara baik dan berkualitas. Kepala sekolah yang memenuhi kriteria dan persyaratan suatu jabatan berarti berwenang atas jabatan atau tugas diberikan dengan kata lain memenuhi persyaratan kompetensi.

Keberadaan madrasah sebagai suatu lembaga yang bergerak pada dunia pendidikan khususnya, tentunya erat kaitannya dengan suatu visi dari madrasah/lembaga tersebut. Menurut Wahyudi, visi sekolah merupakan gambaran masa depan sekolah yang dicita-citakan. Visi dapat membimbing dan menawarkan arah dan peta ke masa depan dan menjadi panduan/petunjuk bagi seluruh anggota organisasi dalam mencapai tujuan. Daftar atau rincian tugas kepala madrasah termasuk peran dan fungsi yang dijalankan dapat menjadi dasar bagi penentuan kompetensi kepala madrasah. Dengan demikian, kompetensi yang perlu dimiliki kepala madrasah meliputi: a) merumuskan visi, b) merencanakan program, c) komunikasi dan kerjasama, d) hubungan masyarakat, e) mengelola sumberdaya sekolah, f) mengambil keputusan, g) mengelola konflik.

Kompetensi kepala madrasah sebagaimana tertulis dalam Peraturan Menteri Pendidikan Nasional Republik Indonesia Nomor 13 Tahun 2007, tentang Standar Kepala Sekolah/Madrasah setidaknya ada lima kompetensi yang harus dimiliki oleh kepala madrasah diantaranya kompetensi kepribadian, kompetensi manajerial, kompetensi kewirausahaan, kompetensi supervisi, dan kompetensi sosial.

Rencana Strategi Badan Litbang dan Diklat Kementerian Agama 2010-2014. Kementerian Agama Badan Litbang dan Diklat Tahun 2010. Arismunandar, 2008. Prilaku Organisasi Dalam Pendidikan. Makassar: Badan Penerbit UNM. hal. 74

Achmadudin, dkk. 2006. Kompetensi Kepala Madrasah. Jurnal Edukasi. Puslitbang Pendidikan Agama dan Keagamaan Badan Litbang dan Diklat Departemen Agama RI. Volume 4 Nomor 3 Juli-September 2006. hal.96

Wahyudi, 2009. Kepemimpinan Kepala Sekolah Dalam Organisasi Pembelajaran (Learning Organization). Bandung: Alfabeta. h. 28 Ibid, h.36 


\section{a. Kompetensi Kepribadian}

Pribadi adalah akar struktural dari kepribadian, sedangkan kepribadian adalah pola perilaku seseorang di dalam dunia ini. ${ }^{6}$ Secara filosofi dapat dikatakan bahwa pribadi adalah "aku yang sejati" dan kepribadian merupakan "penampakan sang aku" dalam bentuk prilaku tertentu.

Kepribadian sering diartikan dengan ciri-ciri yang menonjol pada diri individu, seperti kepada orang yang pemalu dikenakan atribut "berkepribadian pemalu". Kepada orang supel diberikan atribut "berkepribadian supel" dan kepada orang yang plin-plan, pengecut, dan semacamnya diberikan atribut "tidak punya kepribadian".'

Perkembangan kepribadian menurut Lewin dalam Sumadi Suryabrata berpendapat bahwa keturunan atau kematangan penting peranannya dalam perkembangan individu, hakekat perkembangan itu adalah perubahanperubahan tingkah laku (behavioral change), di antaranya:

Perkembangan berarti perubaha'n dalam variasi tingkah laku

Perkembangan berarti perubahan dalam organisasi dan struktur tingkah laku

Perkembangan berarti bertambah luasnya arena aktivitas

Perkembangan berarti perubahan dalam taraf realitas

Perkembangan berarti makin terdiferensiasinya tingkah laku

Perkembangan berarti diferensiasi dan stratifikasi. $^{8}$

\section{b. Kompetensi Supervisi}

Menurut konsep kuno supervisi dilaksanakan dalam bentuk "inspeksi" atau mencari kesalahan guru dalam melaksanakan tugas mengajar. Sedangkan dalam pandangan modern supervisi adalah berusaha untuk memperbaiki situasi belajar mengajar.'

Supervisi merupakan bantuan bagi guru dalam meningkatkan kualitas mengajar untuk membantu peserta didik agar lebih baik dalam belajar. Kenyataan beranggapan bahwa supervisi pendidikan identik dengan pengawasan yang bersifat inspeksi.

Manajemen dipahami sebagai proses mencapai hasil melalui dan dengan orang lain dan memaksimalkan sumberdaya yang tersedia. Dilihat dari teori manajemen bahwa supervisi sebagai bagian dari manajemen khususnya berkaitan dengan kepemimpinan dan controlling sering diterjemahkan sebagai pengawasan. Namun supervisi mempunyai arti khusus yaitu "membantu" dan turut serta dalam usaha-usaha perbaikan dan meningkatkan mutu baik personel maupun lembaga. ${ }^{10}$

Peran supervisor seyogyanya berkaitan dengan pelaksanaan pekerjaan secara langsung dengan mengkoordinasikan pelaksanaan tugas melalui pengarahan dan balikan (feedback) yang efektif dan efisien. Pada konsep manajemen, supervisi dalam dunia pendidikan memandang guru sebagai bagian penting dari manajemen yang diharapkan melaksanakan tugas sesuai fungsi-fungsi manajemen dengan baik dan terukur.

\section{c. Kompetensi Sosial}

Dalam kehidupan sosial, selalu terdapat kompleksitas kepribadian manusia, kebudayaan, minat dan bakat, kebutuhan dan kepentingan yang berbeda. Lembaga pendidikan dipenuhi oleh orang-orang yang memiliki karakter yang berbeda-beda, anak didik berasal dari unsur masyarakat yang beragam, dan masyarakat berasal dari unsur keluarga yang berbedabeda itu dijadikan kekuatan untuk membangun visi pendidikan kedepan. Perbedaan adalah potensi untuk dikembangkan melalui sistem pendidikan yang terarah dan bertujuan.

Lembaga pendidikan merupakan suatu sistem sosial. Asumsi dasar tentang sistem sosial adalah sebagai berikut:"

\section{Wadah untuk berbagai potensi}

Alat untuk mengembangkan bakat manusia Metode untuk mencapai tujuan bersama Strategi untuk membangun masa depan umat manusia

\footnotetext{
Djaali. 2009. Psikologi Pendidikan. Cetakan Keempat. Jakarta: Bumi Aksara. h. 2

Baitul Alim, Muhammad. 2009. Pengertian Kepribadian Menurut Awam dan Psikologi. (http://www.psikologizone.com/pengertiankepribadian-menurut-awam-dan-psikologi). Diakses 27 Desember 2010.

Sumadi Suryabrata, 2002. Psikologi Kepribadian. Jakarta: PT. RajaGrafindo Persada. h. 240

Syaiful Sagala. 2010. Supervisi Pembelajaran Dalam Profesi Pendidikan. Bandung: Afabeta. h. 88

Ibid. h. 89

Himat. Ibid. h. 149
} 
Media untuk mengarahkan prilaku manusia dengan pijakan ilmu pengetahuan yang benar Visi dan misi dalam membangun pandangan dan mewujudkan cita-cita yang beragam sesuai motivasi masyarakat dalam memanfaatkan ilmu pengetahuan yang diperoleh dari pendidikan.

\section{Kepala Madrasah}

Kepala madrasah sebagai pimimpin dalam menduduki jabatan tersebut haruslah memiliki ketentuan, kriteria dan persyaratan. Ketentuan tentang standar kepala sekolah/madrasah, bahwa kualifikasi kepala sekolah/madrasah terdiri atas kualifikasi umum, dan kualifikasi khusus. ${ }^{12}$

1. Kualifikasi umum kepala sekolah/madrasah adalah sebagai berikut:

a. Memiliki kualifikasi akademik sarjana (SI) atau diploma empat (DIV) kependidikan atau non kependidikan pada perguruan tinggi yang terakreditasi.

b. Pada waktu diangkat sebagai kepala sekolah berusia setinggi-tingginya 56 tahun.

c. Memiliki pengalaman mengajar sekurangkurangnya 5 (lima) tahun jenjang sekolah masing-masing, kecuali di taman kanakkanank/raudhatul athfal (TK/RA) memiliki pengalaman mengajar sekurang-kurangnya 3 (tiga) tahun di TK/RA, dan

d. Memiliki pangkat serendah-rendahnya III/c bagi pegawai negeri sipil (PNS) dan bagi non PNS disetarakan dengan kepangkatan yang dikeluarkan oleh yayasan atau lembaga yang berwewenang.

2. Kualifikasi khusus kepala sekolah/madrasah meliputi:

a. Kepala Sekolah Dasar/Madrasah Ibtidaiyah (SD/MI) adalah sebagai berikut:

Berstatus sebagai guru SD/MI

Memiliki sertifikasi pendidik sebagai guru SD/MI

Memiliki sertifikasi kepala SD/MI yang diterbitkan oleh lembaga yang telah ditetapkan pemerintah. b. Kepala Sekolah Menengah Pertama/ Madrasah Tsanawiyah (SMP/MTs) adalah sebagai berikut:

Berstatus sebagai guru SMP/MTs

Memiliki sertifikasi pendidik sebagai guru SMP/MTs

Memiliki sertifikasi kepala SMP/MTs yang diterbitkan oleh lembaga yang telah ditetapkan pemerintah.

c. Kepala Sekolah Menengah Atas/MadrasahAliyah

(SMA/MA) adalah sebagai berikut:

Berstatus sebagai guru SMA/MA

Memiliki sertifikasi pendidik sebagai guru SMA/MA

Memiliki sertifikasi kepala SMA/MA yang diterbitkan oleh lembaga yang telah ditetapkan pemerintah.

Kepala madrasah sebagai seorang pemimpin tidak hanya dituntut memiliki kualifikasi akademik. Kepemimpinan sebagai suatu proses pengarahan dan usaha mempengaruhi aktivitas yang berkaitan dengan tugas dari para anggota kelompok. Kepemimpinan tidak terlepas dari siapa yang memimpin. Menurut Husain Umar terdapat lima landasan kepemimpinan yang kokoh, yaitu: cara berkomunikasi, cara memberikan motivasi, kemampuan memimpin, kemampuan mengambil keputusan, dan kekuasaan positif. $^{13}$

Tugas kepemimpinan kepala madrasah tersebut akan berhasil dengan baik apabila seorang kepala madrasah memahami akan tugas yang harus dilaksanakannya. Oleh sebab itu, kepala madrasah akan tampak dalam proses di mana dia mampu mengarahkan, membimbing, mempengaruhi dan atau menguasai pikiran-pikiran, perasaan-perasaan atau tingkah laku orang lain. Untuk keberhasilan dalam pencapaian tujuan madrasah diperlukan kepemimpinan kepala madrasah yang profesional, di mana ia memahami akan tugas dan kewajibannya sebagai seorang pemimpin, serta melaksanakan peranannya sebagai seorang pemimpin.

Berdasarkan Peraturan Menteri Pendidikan Nasional Nomor 13 Tahun 2007

Husain Umar. 2008. Desain Penelitian MSDM dan Prilaku Karyawan, Paradigma Positif dan Berbasisi Pemecahan Masalah. Jakarta: Rajawali Pers. h. 38 


\section{HASIL DAN PEMBAHASAN}

\section{Identitas Responden}

1. Usia

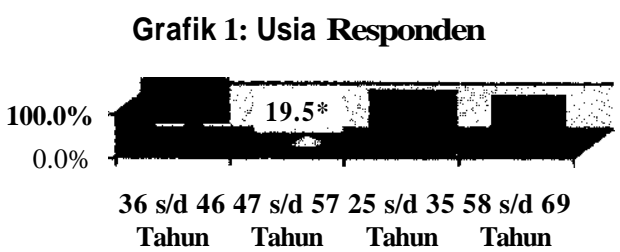

Pada grafik 1, menunjukkan tingkat usia responden bervariasi yaitu 25 sampai 69 tahun. Pada umumnya usia responden didominasi pada usia antara $36 \mathrm{~s} / \mathrm{d} 46$ tahun yaitu, sebanyak 24 orang $(57,1 \%)$, kemudian tingkatan usia antara $47 \mathrm{~s} / \mathrm{d} 57$ tahun sebanyak 8 orang (19\%), selanjutnya tingkatan usia antara $25 \mathrm{~s} / \mathrm{d} 35$ tahun sebanyak 7 orang $(16,7 \%)$, dan untuk tingkatan usia antara $55 \mathrm{~s} / 69$ hanya sebanyak 2 orang $(4,8 \%)$.

\section{Pendidikan}

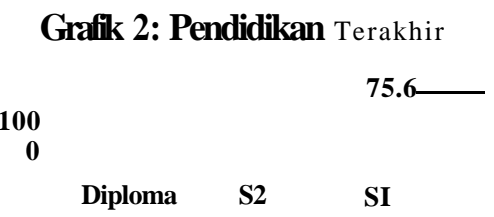

Pada grafik 2 diatas memperlihatkan bahwa tingkat pendidikan kepala madrasah dorninan S1 yaitu sebanyak 31 atau (75,6\%), kemudian diploma sebanyak 7 atau $(17,1 \%$ o), dan hanya terdapat 3 atau $(7,3 \%)$ kepala madrasah dengan pendidikan terakhir S2.

\section{Masa Kerja Kepala Madrasah}

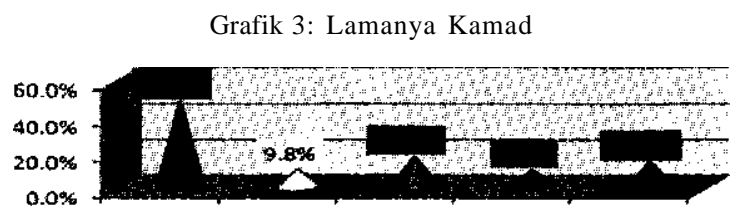

Grafik 3 diatas menunjukkan bahwa masa kerja kepala madrasah didominasi oleh tingkat masa kerja 2 tahun yaitu sebanyak 20 orang $(48,8 \%)$, kemudian dengan masa kerja 4 tahun sebanyak 7 orang $(17,1 \%)$, selanjutnya untuk masa kerja 6 tahun sebanyak 6 orang $(14,3 \%)$, dan yang yang terakhir adalah untuk masa kerja 3 dan 5 tahun masing-masing 4 orang $(9,8 \%)$.

\section{Jenis Kelamin}

\section{Grafik 4: Jenis Kelamin}

Laki-laki Perempuan
Tampak terlihat pada grafik diatas, bahwa dari 41 kepala madrasah yang dijadikan sampel dalam penelitian ini terdapat 33 atau $(80,5 \%)$ orang kepala madrasah berjenis kelamin laki-laki, dan selebihnya 8 atau $(19,5 \%>)$ orang saja yang berjenis kelamin perempuan.

\section{Tempat Bertugas}

Grafik 5: Jenjang Madrasah

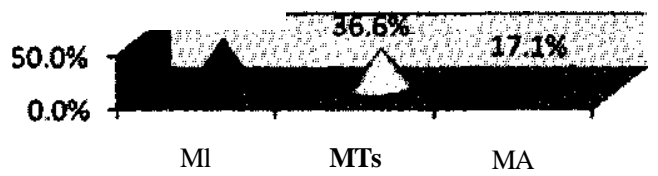

Jumlah madrasah yang ada di Kabupaten dan Kota Sorong sebanyak 41 madrasah dari semua jenjang. Tempat bertugas para kepala madrasah dorninan adalah di Madrasah Ibtidaiyah (MI) yaitu sebanyak 19 atau (46,3\%), kemudian Madrasah Tsanawiyah (MTs) sebanyak 15 atau $(36,6 \%)$, dan kepala madrasah yang bertugas di Madrasah Aliyah (MA), yaitu sebanyak 7 atau $(17,1 \%)$.

\section{Kompetensi Kepala Madrasah}

\section{Supervisi}

Tabel 1:

Kompetensi Kamad Berdasarkan Aspek

\begin{tabular}{|r|l|c|c|}
\hline No & \multicolumn{1}{|c|}{ Kompetensi } & Rerata & Tingkat \\
\hline 1 & Supervisi & $\mathbf{5 9 , 7 1}$ & Sedang \\
\hline 2 & Kepribadian & $\mathbf{6 8 , 8 5}$ & Sedang \\
\hline 3 & Sosial & $\mathbf{5 8 , 4 4}$ & Sedang \\
\hline & KOMPETENSI KAMAD & $\mathbf{6 2} \wedge 3$ & Sedang \\
\hline
\end{tabular}

$$
\begin{array}{cl}
\text { Keterangan : }<50 & - \text { Rendah } \\
51-75 & =\text { Sedang } \\
\mathbf{7 6 - 1 0 0} & =\text { Tinggi }
\end{array}
$$

Gambaran kompetensi kepala madrasah secara keseluruhan menunjukkan bahwa di Kota dan Kabupaten Sorong dari semua jenjang madrasah (MI, MTs, dan MA) baik negeri/swasta, secara umum berada pada kategori Sedang dengan rerata 62,33.

Tabel 2:

Kompetensi Kamad Berdasarkan Rata2, Max, Min, SD

\begin{tabular}{|r|l|r|r|}
\hline No & \multicolumn{1}{|c|}{ Kategori } & \multicolumn{1}{c|}{ Skor } & \multicolumn{1}{c|}{ Nilai } \\
\hline 1 & Rerata & $\mathbf{2 0 , 5 6}$ & $\mathbf{5 9 , 7 1}$ \\
\hline 2 & Minimal & 12 & 34 \\
\hline 3 & Maksimal & 28 & 89 \\
\hline 4 & Range & 16 & 55 \\
\hline 5 & Standar Deviasi & $\mathbf{4 , 2 2}$ & $\mathbf{1 3 , 1 9}$ \\
\hline 6 & Skor Ideal & 35 & 100 \\
\hline
\end{tabular}


Dari tabel di atas menunjukkan, bahwa skor ideal 100 dengan nilai minimal 34 dan nilai maksimal 89. Indikasi tersebut menggambarkan bahwa kompetensi supervisi kepala madrasah cukup bervariasi dengan range sebesar 55, sedangkan standar deviasi 13,19. Sehingga kompetensi supervise terkategori sedang dengan nilai rerata 59,71.

Tabel 3:

Kategori Tingkat Kompetensi R,S,T

\begin{tabular}{|l|c|c|c|c|}
\hline \multirow{2}{*}{ Kriteria } & \multicolumn{3}{|c|}{ Kategori } & \multirow{2}{*}{ Jumlah } \\
\cline { 2 - 4 } & Rendah & Sedang & Tinggi & \\
\hline Frekwensi & 9 & $\mathbf{2 6}$ & $\mathbf{6}$ & $\mathbf{4 1}$ \\
\hline Persen & $\mathbf{2 2 \%}$ & $\mathbf{6 3 , 4} \%$ & $\mathbf{1 4 , 6 \%}$ & $\mathbf{1 0 0 \%}$ \\
\hline
\end{tabular}

Berdasarkan tabel di atas, menunjukkan bahwa, dari 41 responden dengan kriteria $9(22 \%)$ terkategori rendah, $26(63 \%)$ terkategori sedang, dan $6(14,6 \%)$ terkategori tinggi. Sehingga secara keseluruhan tingkat kompetensi supervisi kepala madrasah terkategori sedang.

Tabel 4:

Jawaban Responden Setiap Soal

\begin{tabular}{|c|l|c|}
\hline No & \multicolumn{1}{|c|}{ Pernyataan } & $\begin{array}{c}\text { Nilai } \\
\text { Rerata }\end{array}$ \\
\hline 1 & Merencanakan program supervisi akademik & 70,7 \\
\hline 2 & Melakukati supervisi dengan pendekatan konsultatif & \multirow{2}{*}{80,5} \\
\hline 3 & Melakukan program supervisi kiinis & \multirow{2}{*}{95,1} \\
\cline { 1 - 2 } $\mathbf{4}$ & $\begin{array}{l}\text { Dalam melakukan supervisi, Kepala Madrasah } \\
\text { menggunakan teknik: }\end{array}$ & \multirow{2}{*}{90,3} \\
\cline { 1 - 2 } a. & Kunjungan Kelas & \\
\cline { 1 - 2 } b. & Dtskusi dengan guru secara individu maupun kelompok \\
\cline { 1 - 2 } c. Simulasi Pembelajaran & $\begin{array}{l}\text { Memaniaatkan hasil supervisi akademik dim rangka } \\
\text { meningkatkan profesionalisme guru. }\end{array}$ &
\end{tabular}

Adapun indikator dalam mengukur tingkat kompetensi supervisi kepala madrasah, terlihat dari 7 item pertanyaan, hanya melakukan program supervisi kiinis, melakukan supervisi dengan menggunakan teknik kunjungan kelas, dan teknik simulasi pembelajaran. Dalam implementasinya belum berjalan secara maksimal.

\section{Kepribadian}

Tabel 7:

Kompetensi Kamad Berdasrkan Rata2, Max, Min, SD

\begin{tabular}{|r|l|r|r|}
\hline & Rerata & $\mathbf{2 0 , 6 6}$ & $\mathbf{6 8 , 8 5}$ \\
\hline $\mathbf{2}$ & Minimal & $\mathbf{1 5}$ & $\mathbf{5 0}$ \\
\hline $\mathbf{3}$ & Maksimal & $\mathbf{2 4}$ & $\mathbf{8 0}$ \\
\hline $\mathbf{4}$ & Range & $\mathbf{9}$ & $\mathbf{3 0}$ \\
\hline $\mathbf{5}$ & Standar Deviasi & $\mathbf{2 , 5 0}$ & $\mathbf{8 , 3 9}$ \\
\hline $\mathbf{6}$ & Skor Ideal & $\mathbf{3 0}$ & $\mathbf{1 0 0}$ \\
\hline
\end{tabular}

Dari tabel di atas menunjukkan, bahwa skor ideal 100 dengan nilai minimal 50 dan nilai maksimal 80 . Indikasi tersebut menggambarkan bahwa kompetensi kepribadian kepala madrasah cukup bervariasi dengan range sebesar 30, sedangkan standar deviasi 8,39. Sehingga kompetensi kepribadian terkategori sedang dengan nilai rerata 68,85 .

Tabel 6:

Kategori Tingkat Kompetensi R, S, T.

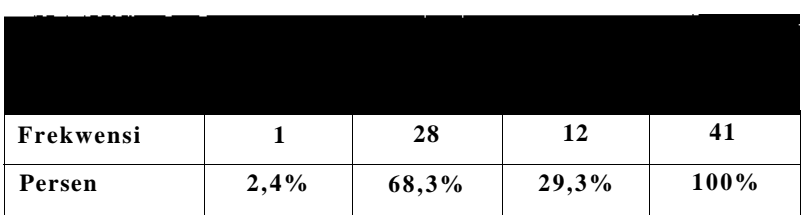

Berdasarkan tabel di atas, menunjukkan bahwa, dari 41 responden dengan kriteria $1(2,4 \%)$ terkategori rendah, 28 (68,3\%) terkategori sedang, dan 12 (29,3\%) terkategori tinggi. Sehingga secara keseluruhan tingkat kompetensi kepribadian kepala madrasah terkategori Sedang. Seyogiyannya kepala madrasah perlu memiliki bakat dalam memimpin suatu pendidikaa

Tabel 7: Jawaban Responden Setiap Soal

\begin{tabular}{|c|l|c|}
\hline No & \multicolumn{1}{|c|}{ Pernyataan } & $\begin{array}{c}\text { Nilai } \\
\text { Rerata }\end{array}$ \\
\hline 1 & Menjadi teladan akhlak mulia bag! guru, staf dan siswa & 100 \\
\hline 2 & Memiliki integritas kepribadian sebagai pemimpin & 92,6 \\
\hline 3 & $\begin{array}{l}\text { Memiliki keinginan yang kuat dim mengembangkan diri } \\
\text { sebagai kepala madrasah }\end{array}$ & 92,7 \\
\hline 4 & $\begin{array}{l}\text { Bersifat lerbuka dalam melaksanakan tugas dan fimgsi } \\
\text { sebagai kepala madrasah }\end{array}$ & \multirow{2}{*}{ too } \\
\hline 5 & $\begin{array}{l}\text { Mampu mengendalikan diri dim menghadapi masalah } \\
\text { yang dihadapi dim pekerjaan sebagai kepala nmadrasah }\end{array}$ & \multicolumn{2}{|c}{} \\
\cline { 1 - 2 } 6 & $\begin{array}{l}\text { Memiliki bakat dan minat jabatan sebagai pemimpin } \\
\text { pendidikan }\end{array}$ &
\end{tabular}

Adapun indikator dalam mengukur tingkat kompetensi kepribadian kepala madrasah, terlihat dari 6 item pertanyaan, hanya memiliki bakat dan minat jabatan sebagai pemimpin pendidikan. Kepala madrasah kurang menunjukkan minat dan bakatnya.

\section{Sosial}

Tabel 8:

Kompetensi Kamad Berdasarkan Rata2, Max, Min, SD

\begin{tabular}{|r|l|r|r|}
\hline 1 & Rerata & $\mathbf{2 9 , 2 1}$ & $\mathbf{5 8 , 4 4}$ \\
\hline 2 & Minimum & $\mathbf{1 7}$ & $\mathbf{3 4}$ \\
\hline 3 & Makstmum & $\mathbf{4 0}$ & $\mathbf{8 0}$ \\
\hline 4 & Range & $\mathbf{2 3}$ & $\mathbf{4 6}$ \\
\hline $\mathbf{5}$ & Standar Deviasi & $\mathbf{5 , 7 6}$ & $\mathbf{1 1 , 5 3}$ \\
\hline $\mathbf{6}$ & Skor Ideal & $\mathbf{5 0}$ & $\mathbf{1 0 0}$ \\
\hline
\end{tabular}


Dari tabel di atas menunjukkan, bahwa skor ideal 100 dengan nilai minimal 34 dan nilai maksimal 80 . Indikasi tersebut menggambarkan bahwa kompetensi sosial kepala madrasah cukup bervariasi dengan range sebesar 46, sedangkan standar deviasi 11,53. Sehingga kompetensi sosial terkategori sedang dengan nilai rerata 58,44 .

\section{Tabel 9:}

\section{Kategori Tingkat Kompetensi R, S, T}

\begin{tabular}{|l|c|c|c|c|} 
Frekwensi & 11 & 27 & 3 & 41 \\
\hline Persen & $\mathbf{2 6 , 8} \%$ & $\mathbf{6 5 , 9} \%$ & $\mathbf{7 3} \%$ & $\mathbf{1 0 0 \%}$ \\
\hline
\end{tabular}

Berdasarkan tabel di atas, menunjukkan bahwa, dari 41 responden dengan kriteria 11 (26,8\%) terkategori rendah, $27(65,9 \%)$ terkategori sedang, dan $3(7,3 \%)$ terkategori tinggi. Sehingga secara keseluruhan tingkat kompetensi sosial kepala madrasah terkategori Sedang. Perlu adanya peningkatan kegiatan pengabdian masyarakat dan bantuan pada pihak lain.

Tabel 10: Jawaban Responden Setiap Soal

\begin{tabular}{|c|c|c|}
\hline 1 & Bekerjasama dgn pihak lain utk kepentingan madrasah & 83 \\
\hline 2 & Berpartisipasi dalam kegiatan sosial kemasyarakatan & \multirow[t]{2}{*}{92,6} \\
\hline 3 & $\begin{array}{l}\text { Melakakan kegiatan pengabdian masyarakat (pelatihan. } \\
\text { pembimbingan, pemberian bantuan dan sejenisnya) }\end{array}$ & \\
\hline 4 & $\begin{array}{l}\text { Merasa memiliki kepekaan sosial terhadap orang atau } \\
\text { kelompok lain }\end{array}$ & 73,1 \\
\hline 5 & Memberikan bantuan kepada pihak lain dalam bentuk: & \multirow{5}{*}{73,2} \\
\hline & a. Pemikiran & \\
\hline & b. Tenaga & \\
\hline & c. Dana & \\
\hline & Aktif terlibat dalam organisasi profesi: & \\
\hline & a. Pcrsatuan Guru Madrasah/Sekolah & 82,9 \\
\hline & b. Kelompok Kerja Kepala Madrasah (K3M) & 80,5 \\
\hline & c. Kelompok Kerja Madrasah (KKM) & 78 \\
\hline
\end{tabular}

Adapun indikator dalam mengukur tingkat kompetensi kepribadian kepala madrasah, terlihat dari 10 item pertanyaan, hanya melakukan kegiatan pengabdian masyarakat dan memberikan bantuan kepada pihak lain. Dalam pelaksanaannya belum berjalan secara maksimal.

\section{Crostabulasi Identitas Responden Dengan Kriteria Tingkat Kompetensi}

\begin{tabular}{|c|c|c|c|c|c|c|}
\hline \multirow{3}{*}{$7 *$ io } & \multirow{3}{*}{ Kmnpcn-nsl } & \multirow{2}{*}{ Kategori } & \multirow{2}{*}{ Bjiilp } & \multicolumn{2}{|c|}{ t.'ija Rei<po<den } & \multirow[b]{2}{*}{ 58-69 } \\
\hline & & & & $36-4 *$ & - «-*-» & \\
\hline & & & $\begin{array}{c}1 \\
(.14 \%)\end{array}$ & $\begin{array}{c}3 \\
(12,5 \%) \\
\end{array}$ & $\begin{array}{c}1 \\
(123 \%)\end{array}$ & $\begin{array}{c}1 \\
(50 \%)\end{array}$ \\
\hline \multirow[t]{6}{*}{1.} & SUPERV1SI & Sedang & $\begin{array}{c}3 \\
(43 \%) \\
\end{array}$ & $\begin{array}{c}18 \\
(75 \%) \\
\end{array}$ & $\begin{array}{c}5 \\
(633 \%) \\
\end{array}$ & $\begin{array}{c}\mathbf{0} \\
(0 \%) \\
\end{array}$ \\
\hline & & Rendah & $\begin{array}{c}3 \\
(43 \%)\end{array}$ & $\begin{array}{c}3 \\
(12,5 \%)\end{array}$ & $\begin{array}{c}2 \\
(25 \%)\end{array}$ & $\begin{array}{c}\mathrm{i} \\
(\mathbf{5 0} \%)\end{array}$ \\
\hline & & Tinggi & $\begin{array}{c}1 \\
(14 \%) \\
\end{array}$ & $\begin{array}{c}7 \\
(29 \%) \\
\end{array}$ & $\begin{array}{c}3 \\
(38 \%) \\
\end{array}$ & $\begin{array}{c}1 \\
(50 \%)\end{array}$ \\
\hline & KEPRIBADIAN & Sedang & $\begin{array}{c}6 \\
(86 \%) \\
\end{array}$ & $\begin{array}{c}16 \\
(67 \%) \\
\end{array}$ & $\begin{array}{c}5 \\
(62 \%) \\
\end{array}$ & $\begin{array}{c}1 \\
(50 \%) \\
\end{array}$ \\
\hline & & Rendah & $\begin{array}{c}0 \\
(0 \%)\end{array}$ & $\begin{array}{c}1 \\
(4 \%)\end{array}$ & $\begin{array}{c}0 \\
(0 \%)\end{array}$ & $\begin{array}{c}0 \\
(0 \%)\end{array}$ \\
\hline & & Tinggi & $\begin{array}{c}1 \\
(14 \%)\end{array}$ & $\begin{array}{c}1 \\
(4 \%) \\
\end{array}$ & $\begin{array}{c}1 \\
(12 \%)\end{array}$ & 。 \\
\hline \multirow[t]{2}{*}{3.} & SOSIAJ. & Sedang & $\begin{array}{c}3 \\
(43 \%) \\
\end{array}$ & $\begin{array}{c}18 \\
(75 \%)\end{array}$ & $\begin{array}{c}4 \\
(50 \%) \\
\end{array}$ & $\begin{array}{c}2 \\
(100 \%)\end{array}$ \\
\hline & & Rendah & $\begin{array}{c}3 \\
(43 \%)\end{array}$ & & $\begin{array}{c}3 \\
(38 \%)\end{array}$ & $\begin{array}{c}\mathbf{0} \\
(0 \%)\end{array}$ \\
\hline
\end{tabular}

Supervisi, dari 41 responden menggambarkan usia menunjukkan bahwa tingkat kompetensi supervisi kepala madrasah beragam. Pada tingkat usia 25-35,36-46, dan 47-57 Thn memiliki tingkat kompetensi sedang keatas, sedangkan usia 58-69 Thn memiliki tingkat kompetensi tinggi dan rendah Sehingga tingkat kompetensi supervise kepala madrasah, untuk usia 36-46 tahun terkategori sedang, terlihat dari 24 responden hanya 18 (75\%) menyatakan usia ideal.

Kepribadian, dari 41 responden menggambarkan usia menunjukkan bahwa tingkat kompetensi kepribadian kepala madrasah beragam. Pada tingkat usia 25-69 Thn memiliki tingkat kompetensi sedang keatas. Sehingga tingkat kompetensi kepribadian kepala madrasah dengan usia 36-46 tahun terkategori sedang terlihat dari 24 responden hanya $16(67 \%)$ menyatakan usia ideal.

Sosial, dari 41 responden menggambarkan tingkat usia, menunjukkan bahwa tingkat kompetensi sosial kepala madrasah beragam. Pada tingkat usia 36-46, 47-57, dan 58-69 Thn memiliki tingkat kompetensi sedang kebawah, sedangkan 25-35 Thn memiliki tingkat kompetensi sedang dan rendah. Sehingga tingkat kompetensi social kepala madrasah dengan usia 36-46 tahun terkategori sedang, terlihat dari 24 responden hanya $18(75 \%)$ menyatakan usia ideal. 


\section{Tempat Bertugas}

\begin{tabular}{|c|c|c|c|c|c|c|}
\hline \multirow{3}{*}{1.} & \multirow{3}{*}{ SUPERVISI } & Tinggi & $\begin{array}{c}4 \\
\mathrm{~J} 2 \mathrm{I} \%\end{array}$ & 2 & $\begin{array}{c}\mathbf{0} \\
(\mathbf{0} \%)\end{array}$ & 6 \\
\hline & & Sedang & $\begin{array}{c}12 \\
(63 \%)\end{array}$ & $\begin{array}{c}9 \\
(49 \%) \\
\end{array}$ & $\begin{array}{c}5 \\
(72 \%) \\
\end{array}$ & 26 \\
\hline & & Rendah & $\begin{array}{c}3 \\
(16 \%)\end{array}$ & $\begin{array}{c}4 \\
(27 \%)\end{array}$ & $\begin{array}{c}2 \\
(28 \%)\end{array}$ & 9 \\
\hline \multirow{3}{*}{2.} & \multirow{3}{*}{ KEPRIBADIAN } & Tinggi & $\begin{array}{c}6 \\
(31 \%)\end{array}$ & $\begin{array}{c}3 \\
(37 \%)\end{array}$ & $\begin{array}{c}3 \\
(42 \%) \\
\end{array}$ & 12 \\
\hline & & Sedang & $\begin{array}{c}12 \\
(63 \%) \\
\end{array}$ & $\begin{array}{c}12 \\
(63 \%) \\
\end{array}$ & $\begin{array}{c}\mathbf{4} \\
(58 \%) \\
\end{array}$ & 28 \\
\hline & & Rendah & $\begin{array}{c}1 \\
(6 \%)\end{array}$ & $\begin{array}{c}\mathbf{0} \\
\text { (in.) }\end{array}$ & $\begin{array}{c}0 \\
(0 \%)\end{array}$ & 1 \\
\hline \multirow{3}{*}{3.} & \multirow{3}{*}{ SOSIAL } & Tinggi & $\begin{array}{c}2 \\
(11 \%)\end{array}$ & $\begin{array}{c}1 \\
(7 \%)\end{array}$ & $\begin{array}{c}0 \\
(0 \%)\end{array}$ & 3 \\
\hline & & Sedang & $\begin{array}{c}12 \\
(63 \%) \\
\end{array}$ & $\begin{array}{c}9 \\
(60 \%) \\
\end{array}$ & $\begin{array}{c}6 \\
(85 \%) \\
\end{array}$ & 27 \\
\hline & & Rendah & $\begin{array}{c}5 \\
(26 \%)\end{array}$ & $\begin{array}{c}5 \\
(33 \%)\end{array}$ & $\begin{array}{c}1 \\
(15 \%)\end{array}$ & 11 \\
\hline
\end{tabular}

a. Supervisi, dari 41 responden menggambarkan tempat tugasnya menunjukkan bahwa tingkat kompetensi supervisi kepala madrasah beragam. Pada tingkat MI dan MTsN memiliki tingkat kompetensi sedang keatas, dan MA memiliki tingkat kompetensi sedang kebawah. Sehingga tingkat kompetensi supervise kepala madrasah dengan tempat tugas terkategori sedang, dari 19 responden hanya $12(63 \%)$ menyatakan di MI.

b. Kepribadian, dari 41 responden menggambarkan tempat tugasnya menunjukkan bahwa tingkat kompetensi kepribadian kepala madrasah beragam. Pada tingkat MI MTsN, dan MA memiliki tingkat kompetensi sedang keatas. Sehingga tingkat kompetensi kepribadian kepala madrasah dengan tempat tugas di madrasah terkategori sedang, dari 34 responden hanya 24 (70,5\%) menyatakan di Tsanawiyah dan Ibtidaiyah.

c. Sosial, dari 41 responden menggambarkan tempat tugasnya menunjukkan bahwa tingkat kompetensi sosial kepala madrasah beragam. Pada tingkat MI dan MTsN, memiliki tingkat kompetensi sedang keatas, sedangkan MA memiliki tingkat kompetensi sedang kebawah. Sehingga tingkat kompetensi social kepala madrasah dengan tempat tugas terkategori sedang, dari 19 responden hanya 12 (63\%) menyatakan di MI.

\section{Tingkat Pendidikan}

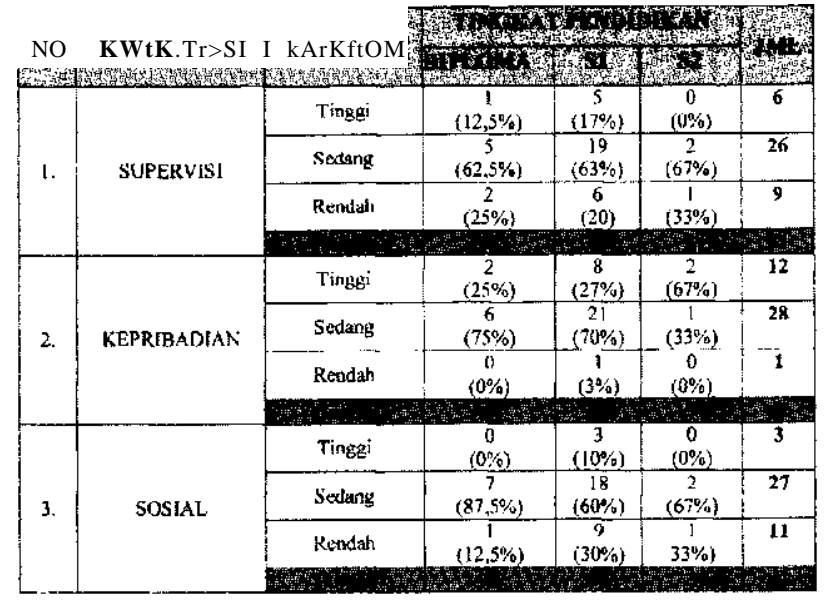

a. Supervisi, dari 41 responden menggambarkan tingkat pendidikan menunjukkan bahwa tingkat kompetensi supervisi kepala madrasah beragam. Pada tingkat D3, SI dan S2 memiliki tingkat kompetensi sedang kebawah. Sehingga tingkat kompetensi supervise kepala madrasah dengan tingkat pendidikan terkategori sedang, dari 30 responden hanya $19 \quad(63 \%)$ menyatakan SI.

b. Kepribadian, dari 41 responden menggambarkan tingkat pendidikan menunjukkan bahwa tingkat kompetensi kepribadian kepala madrasah beragam. Pada tingkat D3 SI, memiliki tingkat kompetensi sedang keatas, sedangkan S2 memiliki tingkat tinggi. Sehingga tingkat kompetensi kepribadian kepala madrasah dengan tingkat pendidikan terkategori sedang, dari 30 responden hanya 21 (70\%) menyatakan SI.

c. Sosial, dari 41 responden menggambarkan tingkat pendidikan menunjukkan bahwa tingkat kompetensi sosial kepala madrasah beragam. Pada tingkat D3, SI, dan S2 memiliki tingkat kompetensi sedang kebawah. Sehingga tingkat kompetensi social kepala madrasah dengan tingkat pendidikan terkategori sedang, dari 30 responden hanya $18(60 \%)$ menyatakan SI. 


\section{Periode Kamad}

\begin{tabular}{|c|c|c|c|c|c|c|c|c|}
\hline No & KU[II|н.'UMI* ${ }^{i}$ & KufORorf & $2 \operatorname{Tin}$ & \multicolumn{2}{|c|}{$<$ Thn $\quad 4 \quad 11 \mathrm{~m}$} & 5 Thn & A Thn & $\mathrm{Jm} \mathbf{m}$ \\
\hline \multirow{3}{*}{1.} & \multirow{3}{*}{ SUPfcRVISI } & Tinggi & $\begin{array}{c}4 \\
(20 \%)\end{array}$ & $\begin{array}{c}0 \\
(0 \%)\end{array}$ & $\begin{array}{c}0 \\
(0 \%)\end{array}$ & $\begin{array}{c}\mathbf{i} \\
(25 \%)\end{array}$ & $\begin{array}{c}\mathbf{1} \\
(17 \%)\end{array}$ & 6 \\
\hline & & Sedang & $\begin{array}{c}\text { II } \\
(55 \%)\end{array}$ & $\begin{array}{c}4 \\
(100 \%) \\
\end{array}$ & $\begin{array}{c}5 \\
(71 \%)\end{array}$ & $\begin{array}{c}3 \\
(75 \%)\end{array}$ & $\begin{array}{c}3 \\
(50 \%) \\
\end{array}$ & 26 \\
\hline & & Rendah & $\begin{array}{c}5 \\
(25 \%)\end{array}$ & $\begin{array}{c}0 \\
(0 » / .)\end{array}$ & $\begin{array}{c}2 \\
(29 \%)\end{array}$ & $\begin{array}{c}0 \\
(0 \%)\end{array}$ & $\begin{array}{c}2 \\
(33 \%)\end{array}$ & 9 \\
\hline \multirow{3}{*}{2.} & \multirow{3}{*}{ KEPRIBADIAN } & Tinggi & $\begin{array}{c}6 \\
(30 \%)\end{array}$ & $\begin{array}{c}0 \\
(0 \%)\end{array}$ & $\begin{array}{c}0 \\
(0 \%)\end{array}$ & $(50 \%)$ & $\begin{array}{c}4 \\
(67 \%)\end{array}$ & 12 \\
\hline & & Sedany & $\begin{array}{c}14 \\
-(\mathrm{J} 0 \%)\end{array}$ & $\begin{array}{c}4 \\
(100 \%)\end{array}$ & $\begin{array}{c}6 \\
(86 \%) \\
\end{array}$ & $\begin{array}{c}2 \\
(50 \%)\end{array}$ & $\begin{array}{c}2 \\
(33 \%) \\
\end{array}$ & 28 \\
\hline & & Rendah & $\begin{array}{c}\text { (I } \\
(0 \%)\end{array}$ & $\begin{array}{c}0 \\
(0 \%)\end{array}$ & $\begin{array}{c}1 \\
(14 \%)\end{array}$ & $\begin{array}{c}0 \\
(0 \%)\end{array}$ & $\begin{array}{c}0 \\
(0 \%)\end{array}$ & 1 \\
\hline \multirow{3}{*}{3.} & \multirow{3}{*}{ SOSIAL } & Tinggi & $\begin{array}{c}2 \\
(10 \%)\end{array}$ & $\begin{array}{c}0 \\
(0 \%) \\
\end{array}$ & $\begin{array}{c}0 \\
(0 \%) \\
\end{array}$ & $\begin{array}{c}1 \\
(25 \%)\end{array}$ & $\begin{array}{c}0 \\
(0 \%) \\
\end{array}$ & 3 \\
\hline & & Sedang & $\begin{array}{c}10 \\
<<^{50}+4 \mathbf{L} \\
\end{array}$ & $\begin{array}{c}2 \\
(50 \%)\end{array}$ & $\begin{array}{c}6 \\
186 \%)\end{array}$ & $\begin{array}{c}3 \\
J \%(\%)\end{array}$ & $\begin{array}{c}6 \\
(10054) \\
\end{array}$ & 27 \\
\hline & & Rendah & $\begin{array}{c}8 \\
(40 \%)\end{array}$ & $\begin{array}{c}2 \\
(50 \%)\end{array}$ & $\begin{array}{c}1 \\
(14 \%)\end{array}$ & $\begin{array}{c}0 \\
(0 \%)\end{array}$ & $\begin{array}{c}0 \\
(0 \%)\end{array}$ & 11 \\
\hline
\end{tabular}

a. Supervisi, dari 41 responden menggambarkan periode menunjukkan bahwa tingkat kompetensi supervisi kepala madrasah beragam. Pada tingkat 2,3 dan 5 Thn memiliki tingkat kompetensi sedang keatas, dan 4-6 Thn memiliki tingkat kompetensi sedang kebawah. Sehingga tingkat kompetensi supervise kepala madrasah dengan periode terkategori sedang, dari 20 responden hanya 11 (55\%) menyatakan 2 Tahun.

b. Kepribadian, dari 41 responden menggambarkan periode menunjukkan bahwa tingkat kompetensi kepribadian kepala madrasah beragam. Pada tingkat 2,3 dan 5 Thn memiliki tingkat kompetensi sedang keatas, untuk 4 Thn memiliki tingkat kompetensi sedang kebawah, sedangkan 6 Thn yang memiliki tingkat kompetensi tinggi. Sehingga tingkat kompetensi kepribadian kepala madrasah dengan periode terkategori sedang, dari 20 responden hanya 14 (70\%) menyatakan 2 Tahun.

c. Sosial, dari 41 responden menggambarkan periode menunjukkan bahwa tingkat kompetensi sosial kepala madrasah beragam. Pada tingkat 2,3,4 dan 6 Thn memiliki tingkat kompetensi sedang kebawah, sedangkan 5 Thn memiliki tingkat kompetensi sedang keatas. Sehingga tingkat kompetensi social kepala madrasah dengan periode terkategori sedang, dari 20 responden hanya $10(50 \%)$ menyatakan 2 Tahun.

\section{Kompetensi Kepala Madrasah Menurut Guru}

\begin{tabular}{|c|c|c|c|}
\hline No & Aspek Kompetensi & Rerata & Kategori \\
\hline 1. & Kompetensi Suprvisi & 2,9 & Sedang \\
\hline 2. & Kompetensi Kepribadian & 3,3 & Tinggi \\
\hline \multirow[t]{2}{*}{3.} & Kompetensi Sosial & 3,1 & Tinggi \\
\hline & Kompetensi Kamad & 3,1 & Tinggi \\
\hline eter & $\begin{aligned} \text { gan }: & 0,0-0,1=\text { Sangat } \\
& 1,1-2,0=\text { Rendah } \\
& 2,1-3,0=\text { Sedang }\end{aligned}$ & 4,1 & $\begin{aligned}-4,0 & =\text { Tin } \\
-5,0 & =\text { San }\end{aligned}$ \\
\hline
\end{tabular}

Berdasarkan hasil analisis deskripsi statistic menunjukkan bahwa secara umum menurut penilaian guru, kompetensi kepala madrasah berada pada kategori Tinggi dengan rerata 3,1. Dari kompetensi tersebut hanya kompetensi supervise yang terkategori Sedang dengan rerata 2,9.

\section{SUPERVISI}

\begin{tabular}{|c|c|c|}
\hline No & Pernyataan & $\begin{array}{c}\text { Skor } \\
\text { Rerata }\end{array}$ \\
\hline 1 & Mereneanakan program supervisi akademik & $2 \mathbf{H}$ \\
\hline 2 & Melakukan supervisi dengan pendekatan konsultatif & 3,1 \\
\hline 3 & Melakukan program supervisi klinis & \\
\hline 4 & $\begin{array}{l}\text { Dalam melakukan supervisi, Kepala Madrasah } \\
\text { menggunakan teknik: }\end{array}$ & \\
\hline \multicolumn{2}{|c|}{ a. Kunjungan Kelas } & \multirow{3}{*}{3,3} \\
\hline b. & Diskusi dengan guru secara individu maupun kelompok & \\
\hline \multicolumn{2}{|r|}{ c. Simulasi Pembelajaran } & \\
\hline 5 & $\begin{array}{l}\text { Memaniaatkan hasil supervisi akademik dim rangka } \\
\text { meningkatkan profesionalisme guru. }\end{array}$ & 3,0 \\
\hline
\end{tabular}

Pada tabel diatas, menunjukkan bahwa pada dimensi kompetensi supervisi kepala madarasah menurut guru terdapat 4 item pertanyaan yang belum direspon secara maksimal yaitu terkait dengan Merencanakaan program supervise akademik dengan respon jawaban 2,8, melakukan program supervise klinis dengan respon jawaban 2,5, kunjungan kelas 2,9. Dan simulasi pembelajaran dengan respon jawaban 2,8 . Sedangakan hanya 3 item pertanyaan direspon dengan ketepatan jawaban yaitu terkait pendekatan konsulatif 3,1, diskusi individu atau kelompok bersama guru 3,3, dan 3,0 menyatakan pemanfaatan hasil supervise akademik dalam peningkatan profesionalime guru, sehingga tingkat kompetensi supervise kepala madrasah terkategori sedang dengan skor rerata 2,9.

\section{KEPRIBADIAN}

\begin{tabular}{|c|l|c|}
\hline No & \multicolumn{1}{|c|}{ Pernyataan } & $\begin{array}{c}\text { Skor } \\
\text { Rerata }\end{array}$ \\
\hline 1 & Menjadi teladan akhlak mulia bagi gum, staf dan siswa & 3,4 \\
\hline 2 & Memiliki integritaa kepribadian sebagai pemimpin & 3,3 \\
\hline 3 & $\begin{array}{l}\text { Memiliki keinginan yang kuat dim mengembangkan diri } \\
\text { sebagai kepala madrasah }\end{array}$ & 3,4 \\
\hline 4 & $\begin{array}{l}\text { Bersifat terbuka dalam melaksanakan tugas dan (ungsi } \\
\text { sebagai kepala madrasah }\end{array}$ & 3,5 \\
\hline 5 & $\begin{array}{l}\text { Mampu mengendalikan diri dim rnenghadapi masalah } \\
\text { yang dihadapi dim pekerjaan sebagai kepala nmadrasah }\end{array}$ & 3,3 \\
\hline 6 & $\begin{array}{l}\text { Memiliki bakat dan minat jabatan sebagai pemimpin } \\
\text { pendidikan }\end{array}$ & 3,1 \\
\hline
\end{tabular}

Pada tabel diatas, menunjukkan bahwa pada dimensi kompetensi kepribadian kepala madarasah menurut guru terdapat 6 item pertanyaan yang direspon secara maksimal yaitu terkait sebagai tauladan, memiliki integritas, mengembangkan diri, terbukan dalam melaksanakan tugas dan fungsi, mampu mengendalikan diri, dan memiliki bakat dan minat sebagai pemimpin pendidikan. Sehingga tingkat kompetensi kepribadian kepala madrasah terkategorikan tinggi dengan skor rerata 3,3. 


\section{SOSIAL}

\begin{tabular}{|c|c|c|}
\hline 1 & Bckcrjasama dgn pihak Iain utk kcpentingan madrasah & 3,1 \\
\hline 2 & Berpartisipasi dalam kegiatan sosial kemasyarakatan & \multirow[t]{2}{*}{3,3} \\
\hline 3 & $\begin{array}{l}\text { Melakukan kegiatan pengabdian masyarakat (pelatihan, } \\
\text { pembimbingan, pemberian bantuan dan sejenisnya) }\end{array}$ & \\
\hline 4 & $\begin{array}{l}\text { Merasa memiliki kepekaan sosial terhadap orang atau } \\
\text { kelompok lain }\end{array}$ & 3,2 \\
\hline $\mathrm{S}$ & Memberikan bantuan kepada pihak lain dalam bentuk: & \multirow{4}{*}{3,1} \\
\hline & a. Pemikiran & \\
\hline & b. Tenaga & \\
\hline & c. Dana & \\
\hline \multicolumn{2}{|r|}{6 j Aktif terlibat dalam organisasi profesi: } & \\
\hline & d. Persatuan Guru Madrasah/Sekolah & 3,5 \\
\hline & e. Kelompok Kerja Kepala Madrasah (K3M) & 3,4 \\
\hline & f. Kelompok Kerja Madrasah (KKM) & 3,5 \\
\hline
\end{tabular}

Pada tabel diatas, menunjukkan bahwa pada dimensi kompetensi sosial kepala madarasah menurut guru terdapat 3 item pertanyaan yang belum direspon secara maksimal yaitu terkait dengan kegiatan pengabdian pada masyarakat dengan respon jawaban 2,9 memberikan bantuan kepada pihak lain dalam bentuk tenaga dan dana dengan respon jawaban 2,6 dan 2,9. Sehingga kompetensi social kepala madrasah terkategorikan tinggi dengan nilai skor rerata 3,1 .

\section{PENUTUP}

\section{A. Kesimpulan}

Tingkat kompetensi kepala madrasah, terukur lewat analisis kategori, yaitu; a) kompetensi total, b) kompetensi rendah, sedang, dan tinggi, c) melalui item pertanyaan, dan d) crostabulasi. Ini menunjukkan bahwa kompetensi kepala madrasah, baik Ibtidaiyah, Tsanawiyah, dan Aliyah (negeri/swasta). Secara keseluruhan kompetensi kepala madrasah terkategori Sedang dengan nilai rerata 62,33 .

Menurut penilaian guru terhadap kompetensi kepala madrasah baik Ibtidaiyah, Tsanawiyah, dan Aliyah (negeri/swasta). Menunjukkan bahwa kepemimpinan kepala madrasah terkategori Tinggi dengan skor rerata 3,1 .

\section{B. Rekomendasi}

Diharapkan Pemerintah (Kementerian Agama dan Kementerian Pendidikan) dalam perekrutan kepala madrasah dan perizinan pembangunan madrasah bisa lebih selektif, agar sasaran pendidikan agama dan keagamaan dapat terwujud serta bisa meningkatkan mutu pengelolaan pendidikan pada madrasah (negeri/ swasta).

Kepala Madrasah seyogiyanya mampu menciptakan kreatifitas, guna mewujudkan kualitas pembelajaran, sehingga dapat bertanggung jawab terhadap administrasi pendidikan.

\section{Ucapan Terima Kasih}

Penelitian ini dibiayai oleh DIPALitbang Agama Makassar Tahun 2011. Ucapan terima kasih diperuntukkan kepada para informan dilapangan khususnya para responden, juga terima kasih kepada teman-teman di bidang pendidikan agama dan keagamaan pada Balai Penelitian Dan Pengembangan Agama Makassar atas kebersamaan kita selama ini.

\section{DAFTAR PUSTAKA}

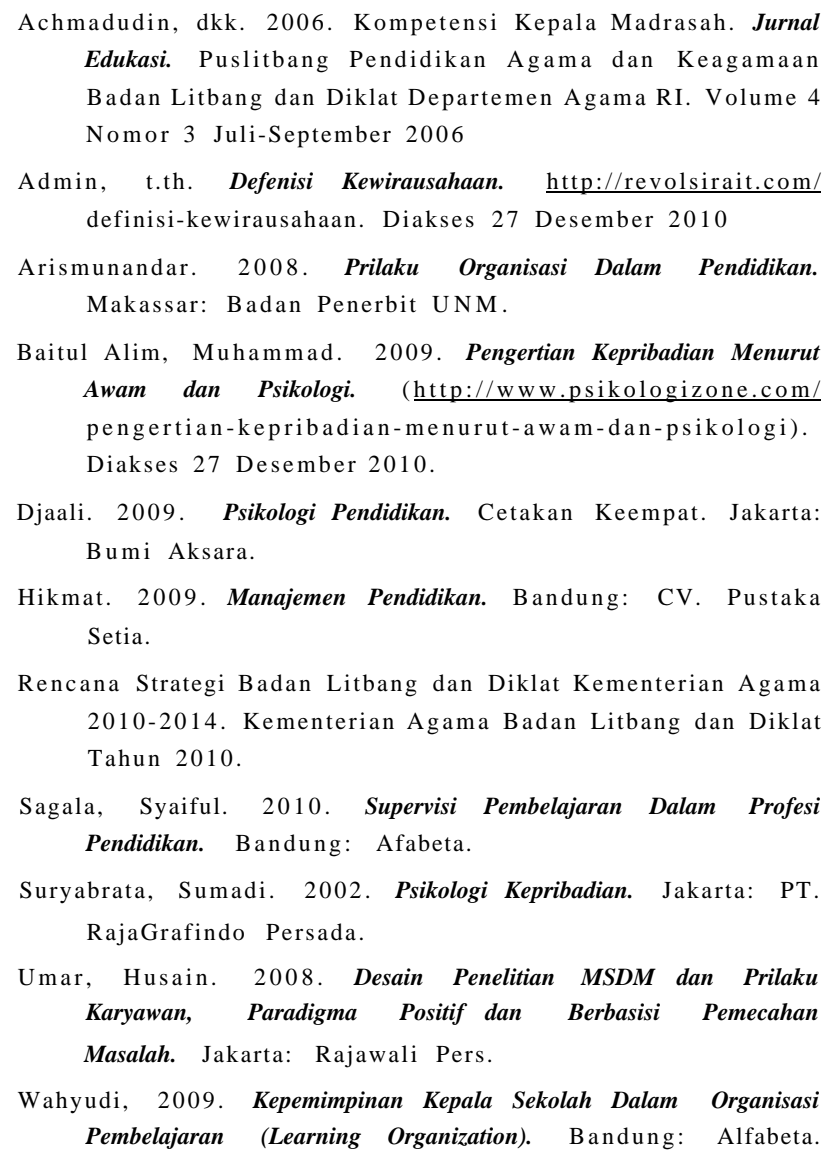

